\title{
Perbandingan bone conduction pada penderita otitis media supuratif kronik dengan kolesteatoma dan tanpa kolesteatoma
}

\author{
Putri Cita Sari Dewi, Titiek Hidayati Ahadiah, Haris Mayagung Ekorini \\ Departemen Ilmu Kesehatan Telinga Hidung Tenggorok-Bedah Kepala dan Leher \\ Fakultas Kedokteran Universitas Airlangga/Rumah Sakit Dr.Soetomo \\ Surabaya
}

\begin{abstract}
ABSTRAK
Latar Belakang: Beberapa peneliti melaporkan adanya sensorineural hearing loss (SNHL) yang dapat terjadi bersamaan atau sebagai sekuele dari Otitis Media Supuratif Kronik (OMSK), yang menunjukkan adanya gangguan fungsi koklea. Kolesteatoma diduga sebagai salah satu faktor risiko terjadinya gangguan fungsi koklea pada OMSK. Tujuan: Membandingkan bone conduction $(\mathrm{BC})$ penderita OMSK dengan kolesteatoma dan tanpa kolesteatoma. Metode: Penelitian crosssectional analitik dari data rekam medik penderita OMSK dengan dan tanpa kolesteatoma yang telah dilakukan mastoidektomi di Rumah Sakit Dr. Soetomo Surabaya pada Januari 2014 hingga November 2016, dengan kriteria inklusi dan eksklusi yang ketat. Dicatat nilai BC sebagai cerminan fungsi koklea, dan ada tidaknya kolesteatoma durante operasi. Durasi otore merupakan faktor perancu dalam perhitungan statistik. Hasil: Dari 111 rekam medik penderita OMSK didapatkan 57 dengan kolesteatoma dan 54 tanpa kolesteatoma. Bone conduction pada penderita OMSK dengan kolesteatoma didapatkan lebih tinggi di semua frekuensi dan paling tinggi di frekuensi $4000 \mathrm{~Hz}$. Uji statistik dengan multiple regression dengan tingkat kemaknaan $(\alpha)$ sebesar 0,05 mendapatkan hasil rerata (mean) BC OMSK dengan kolesteatoma (28,6 dB HL) signifikan lebih tinggi dibandingkan tanpa kolesteatoma $(17,3 \mathrm{~dB}$ HL) dengan $\mathrm{p}=0,002$. Sementara itu, pada durasi otore tidak didapatkan hasil yang signifikan $(\mathrm{p}=0,398)$. Kesimpulan: Penderita OMSK dengan kolesteatoma memiliki BC lebih tinggi dibandingkan tanpa kolesteatoma.
\end{abstract}

Kata kunci: kolesteatoma, bone conduction, gangguan fungsi koklea, OMSK

\begin{abstract}
Background: Some researchers had reported the presence of sensorineural hearing loss (SNHL) which may occur simultaneously or as a sequel of Chronic Suppurative Otitis Media (CSOM) which is indicating impaired cochlear function. Cholesteatoma is suspected to be one of the risk factors for impaired cochlear function in CSOM. Objective: Comparing bone conduction (BC) of CSOM with and without cholesteatoma patients. Method: This was a crossectional analytic study using medical record data of CSOM patients with and without cholesteatoma who underwent mastoidectomy in Dr. Soetomo Hospital from January 2014 to November 2016, with strict inclusion and exclusion criteria. The BC level was recorded as a reflection of cochlear function, and the presence or absence of cholesteatoma during surgery. The otore duration was put down as a confounding factor in statistical calculations. Result: From 111 medical records of CSOM patients were found 57 with cholesteatoma, and 54 without cholesteatoma. Bone conduction in CSOM patients with cholesteatoma is higher in all frequencies and the highest at $4000 \mathrm{~Hz}$. Statistical test using multiple regression with significance level $(\alpha) p=0.05$, revealed the $B C$ mean result of CSOM with cholesteatoma (28.6 dB HL) was significantly higher than on CSOM without cholesteatoma $(17.3 \mathrm{~dB} H L)(p=0.002)$. Meanwhile the otore duration did not reveal a significant result ( $p=0.398)$. Conclusion: CSOM patients with cholesteatoma had a higher BC than those without cholesteatoma.
\end{abstract}

Keywords: cholesteatoma, bone conduction, impaired cochlear function, CSOM

Alamat Korespondensi: Putri Cita Sari Dewi. Departemen Ilmu Kesehatan. Telinga Hidung TenggorokBedah Kepala dan Leher Fakultas Kedokteran Universitas Airlangga/Rumah Sakit Dr. Soetomo. Jl. May. Jend.Dr.Moestopo No.6-8 Surabaya. Email: bundaabah03@gmail.com 


\section{PENDAHULUAN}

Otitis Media Supuratif Kronik (OMSK) masih menjadi masalah kesehatan masyarakat pada beberapa populasi di dunia yang dapat menyebabkan morbiditas dan mortalitas. Salah satu morbiditas yang disebabkan OMSK adalah gangguan pendengaran. Sebanyak $80 \%$ penderita OMSK mengalami gangguan pendengaran. ${ }^{1}$ Jenis gangguan pendengaran yang umumnya terjadi adalah konduktif karena kerusakan tulang pendengaran. Beberapa peneliti melaporkan adanya sensorineural hearing loss (SNHL) yang dapat terjadi bersamaan atau sebagai sekuel dari OMSK yang menunjukkan adanya gangguan fungsi koklea. ${ }^{2-5}$ Kolesteatoma diduga sebagai salah satu faktor risiko terjadinya gangguan fungsi koklea pada OMSK. ${ }^{3-6}$ Kolesteatoma merupakan debris keratin yang menumpuk di kantong epitel skuamosa di dalam telinga tengah atau tulang temporal. Selain dapat menyebabkan erosi tulang pendengaran, kolesteatoma juga dapat menyebabkan erosi tulang labirin. ${ }^{7-9}$

Dalam penelitian retrospektif yang dilakukan di Rumah Sakit Dr. Soetomo Surabaya pada tahun 1999-2002, didapatkan sebanyak 127 dari 475 (26,7\%) kasus OMSK maligna sudah mengalami tuli perseptif berat sampai total. ${ }^{10}$ Beberapa penelitian lain mendapatkan tidak ada perbedaan risiko SNHL pada OMSK dengan dan tanpa kolesteatoma. ${ }^{5,11}$ Fakta ini membuktikan pengaruh kolesteatoma terhadap fungsi koklea masih menjadi kontroversi.

Fungsi koklea dapat diketahui salah satunya dengan pemeriksaan audiometri yang dinyatakan dengan ambang dengar bone conduction (BC). ${ }^{12}$ Wahyudiono $\mathrm{dkk}^{13}$ mendapatkan rata-rata ambang dengar BC pada OMSK dengan kolesteatoma signifikan lebih tinggi dibandingkan tanpa kolesteatoma. Derajat SNHL pada OMSK dengan kolesteatoma didapatkan lebih berat dibandingkan tanpa kolesteatoma. ${ }^{14}$ Kolesteatoma menyebabkan SNHL akibat sifat destruksinya dan sitokin-sitokin pro inflamasi yang masuk melalui foramen rotundum. Agen inflamasi dan toksin bakteri pada OMSK masuk ke telinga dalam melalui foramen rotundum, sehingga menyebabkan kerusakan sel rambut luar, stria vascularis, perubahan osmolaritas, $\mathrm{pH}$, dan kandungan ion di koklea. ${ }^{3}$ Mekanisme ini yang diduga terjadi, sehingga menyebabkan SNHL pada OMSK tanpa kolesteatoma.

Sampai saat ini di Departemen Telinga Hidung Tenggorok-Bedah Kepala dan Leher (THT-KL) Rumah Sakit Dr. Soetomo Surabaya, penelitian mengenai pengaruh kolesteatoma terhadap fungsi koklea dengan menggunakan BC sebagai parameternya belum pernah dilakukan. Tujuan penelitian ini untuk mengetahui apakah ada pengaruh kolesteatoma terhadap fungsi koklea pada penderita OMSK sebagai acuan edukasi kepada pasien dan keluarga mengenai salah satu komplikasi OMSK dengan kolesteatoma.

\section{METODE}

Jenis penelitian ini adalah observasional analitik dengan rancangan cross sectional menggunakan metode retrospektif (dengan data sekunder) dan telah disetujui oleh Komite Etik Rumah Sakit Dr. Soetomo Surabaya. Penelitian dilakukan di Departemen THT-KL Fakultas Kedokteran Universitas Airlangga/ Rumah Sakit Dr. Soetomo Surabaya, menggunakan rekam medis penderita OMSK yang telah dilakukan mastoidektomi sejak 1 Januari 2014 sampai dengan 30 November 2016. Jumlah sampel terbagi menjadi penderita dengan kolesteatoma dan tanpa kolesteatoma dengan kriteria inklusi penderita berusia $6-<65$ tahun, memiliki data audiogram yang lengkap dan tervalidasi yang didapat dari hasil audiometri yang telah menggunakan masking atau sensorineural aquity level (SAL) yang sesuai, dan terdapat laporan operasi yang lengkap. Penderita dengan bilateral mixed hearing loss (MHL)/ sensorineural hearing loss (SNHL) yang memiliki riwayat mastoidektomi sebelumnya didapatkan fiksasi stapes durante operasi dieksklusikan dari penelitian.

Teknik pengambilan sampel adalah dengan simple random sampling. Variabel bebas adalah kolesteatoma, variabel tergantung adalah fungsi koklea, dan variabel 
perancu adalah durasi otore. Hasil BC telinga sakit pada frekuensi 500, 1000, 2000, dan $4000 \mathrm{~Hz}$ yang tertera pada audiogram rekam medis penderita, serta ada atau tidaknya kolesteatoma pada laporan operasi dicatat pada lembar pengumpul data. Bone conduction pada penderita OMSK tanpa kolesteatoma digunakan sebagai kontrol. Durasi otore dicatat sebagai faktor perancu yang dikontrol dengan uji statistik. Hasil $\mathrm{BC}$ dianalisis dengan uji statistik multiple regression dengan tingkat kemaknaan $(\alpha)$ sebesar 0,05 .

\section{HASIL}

Penelitian dilakukan pada 111 rekam medis penderita OMSK yang terdiri dari 57 OMSK dengan kolesteatoma, dan 54 tanpa kolesteatoma. Data penderita didapatkan kelompok umur 11-20 tahun merupakan jumlah paling banyak yaitu sebesar 38 $(34,23 \%)$ penderita. Distribusi berdasarkan jenis kelamin diperoleh perbandingan lakilaki:perempuan=1:1,5. Karakteristik klinis OMSK tanpa kolesteatoma didapatkan jumlah paling banyak yaitu durasi otore didapatkan 1-5 tahun $(31,48 \%)$, gangguan pendengaran tipe konduksi $(83,33 \%)$, dan derajat gangguan pendengaran sedang $(29,63 \%)$. Sementara itu, karakteristik klinis OMSK dengan kolesteatoma didapatkan jumlah paling banyak yaitu durasi otore didapatkan 1-5 tahun $(35,09 \%)$, gangguan pendengaran tipe konduksi $(56,14 \%)$, dan derajat gangguan pendengaran sedang-berat $(35,08 \%)$. Hasil pengendalian durasi otore sebagai variabel perancu terhadap BC tertera pada tabel 2 . Hasil analisis ambang dengar BC pada OMSK dengan dan tanpa kolesteatoma dapat dilihat pada tabel 3 .

Hasil uji statistik dengan multiple regression didapatkan $\mathrm{p}=0,002$. Hal ini menunjukkan ada perbedaan yang signifikan $(p<0,05)$. Berarti ada pengaruh kolesteatoma terhadap fungsi koklea. Frekuensi yang paling dominan mempengaruhi $\mathrm{BC}$ adalah $1000 \mathrm{~Hz}$ $(b=0,294)$, diikuti frekuensi $2000 \mathrm{~Hz}$ dan $4000 \mathrm{~Hz}$. Kontribusi pengaruh kolesteatoma pada seluruh frekuensi didapat sebesar $29 \%$ $(b=0,290)$.

\section{Tabel 1. Karakteristik klinis}

\begin{tabular}{lcccc}
\hline \multirow{2}{*}{ Karakteristik klinis } & \multicolumn{2}{c}{ OMSK dengan kolesteatoma } & \multicolumn{2}{c}{ OMSK tanpa kolesteatoma } \\
\cline { 2 - 4 } & Jumlah & \% & Jumlah & \% \\
\hline Durasi otore (tahun) & 9 & 15,79 & 11 & 20,37 \\
$<1$ & 20 & 35,09 & 17 & 31,48 \\
$1-5$ & 16 & 28,07 & 10 & 18,52 \\
$6-10$ & 5 & 8,77 & 2 & 3,70 \\
$11-15$ & 7 & 12,28 & 14 & 25,93 \\
$>15$ & & & 9,26 \\
& 1 & & 5 & 7,33 \\
\hline Jenis gangguan pendengaran & 32 & 1,76 & 45 & 0,00 \\
Normal & 21 & 56,14 & 4 & \\
Konduksi & 3 & 36,84 & 0 & 9,26 \\
Campuran & & 5,26 & & 27,78 \\
Sensorineural & & & 29,63 \\
Derajat gangguan pendengaran & 2 & 3,51 & 25,92 \\
Normal & 8 & 14,04 & 7,41
\end{tabular}


Tabel 2. Hasil pengendalian durasi otore sebagai variabel perancu terhadap BC

\begin{tabular}{cc}
\hline Frekuensi $(\mathbf{H z})$ & $\mathbf{p}$ \\
\hline 500 & $0,198^{*}$ \\
1000 & $0,549^{*}$ \\
2000 & $0,888^{*}$ \\
4000 & $0,216^{*}$ \\
Rerata & $0,398^{*}$ \\
\hline
\end{tabular}

*Signifikan $<0,05$

Tabel 3. Perbandingan nilai BC

\begin{tabular}{|c|c|c|c|c|}
\hline \multirow{3}{*}{$\begin{array}{l}\text { Frekuensi } \\
\qquad(\mathrm{Hz})\end{array}$} & \multicolumn{2}{|c|}{$B C(d B)$} & \multirow{3}{*}{$\mathbf{p}$} & \multirow{3}{*}{ B } \\
\hline & OMSK dengan kolesteatoma & OMSK tanpa kolesteatoma & & \\
\hline & $\bar{x}(\mathrm{SD})$ & $\bar{x}(\mathrm{SD})$ & & \\
\hline 500 & $23,33(21,03)$ & $14,35(14,07)$ & $0,010^{*}$ & 0,244 \\
\hline 1000 & $26,49(24,98)$ & $13,98(14,35)$ & $0,002 *$ & 0,294 \\
\hline 2000 & $31,23(22,91)$ & $20,00(17,07)$ & $0,004 *$ & 0,269 \\
\hline 4000 & $31,84(23,63)$ & $20,37(17,43)$ & $0,005^{*}$ & 0,267 \\
\hline Rerata (dB HL) & $28,60(21,59)$ & $17,30(13,82)$ & $0,002 *$ & 0,290 \\
\hline
\end{tabular}

\section{DISKUSI}

Kelompok umur 11-20 tahun memiliki jumlah terbanyak yaitu $15(45,45 \%)$ penderita. Kelompok umur ini merupakan kelompok masa sekolah. Hasil penelitian ini sesuai dengan survei kesehatan indra penglihatan dan pendengaran tahun 1994-1996 pada tujuh provinsi di Indonesia. Survei tersebut didapatkan prevalensi OMSK 3,1\% populasi dengan umur penderita infeksi telinga tengah terbanyak 7-18 tahun yaitu kelompok masa sekolah. ${ }^{8}$ Hasil yang sama didapatkan pada penelitian oleh Nursiah yang melaporkan kelompok umur 12-20 tahun sebagai prosentase tertinggi yaitu 33,33\% (12 dari 40) penderita OMSK. ${ }^{15}$ World Health Organization (WHO) menyebutkan bahwa prevalensi OMSK berdasarkan survei di beberapa negara ditemukan banyak pada anak usia sekolah. ${ }^{16}$ Insiden OMSK dengan kolesteatoma di Amerika ditemukan pada anak usia 10-19 tahun sebanyak 9,2 kasus dalam 100.000 populasi. Demikian juga di Israel didapatkan insiden OMSK dengan kolesteatoma pada anak umur 1-15 tahun sebanyak 39 kasus per 100.000 populasi. ${ }^{9}$

Kejadian infeksi telinga tengah banyak pada 6 tahun pertama dengan puncak pada umur 2 tahun, dan menurun sejalan pertambahan umur anak. Sampai saat ini waktu peralihan dari Otitis Media Supuratif Akut (OMSA) menjadi OMSK masih kontroversial. Akan tetapi, prevalensi OMSK ditemukan banyak pada masa sekolah dan dewasa muda. Tingginya insidensi OMSK pada umur kurang dari 10 tahun disebabkan oleh anatomi tuba Eustachius yang relatif pendek dan lurus, higiene dan perilaku sehat yang kurang baik, status imun yang rendah, sehingga mudah menderita infeksi saluran nafas atas. Sementara itu, pada umur lebih dari 18 tahun disebabkan status ekonomi yang rendah dan penanganan infeksi kronik yang tidak adekuat. ${ }^{17}$

Perbandingan perempuan lebih banyak dibanding laki-laki yaitu sebesar 1,5:1. Hasil ini serupa dengan penelitian di Medan yang didapatkan penderita laki-laki sebesar $39,3 \%$ dan perempuan sebesar $60,6 \%$ pada 33 penderita OMSK selama tiga bulan. ${ }^{18}$ Pada penelitian Sharma $\mathrm{dkk}^{5}$ didapatkan $36 \%$ penderita laki-laki, dan $64 \%$ penderita perempuan. Penelitian yang dilakukan di Jaipur dan Dhaka menunjukkan hal yang bertentangan. ${ }^{19,20}$ Keduanya menemukan penderita OMSK lebih banyak pada laki-laki dibandingkan pada perempuan. Penelitian oleh Faridah $\mathrm{dkk}^{21}$ menyebutkan bahwa tidak ada perbedaan bermakna antara jenis kelamin dengan otitis media. Berbagai analisa faktor risiko pada beberapa kepustakaan 
tidak menyebutkan adanya kecenderungan terjadinya OMSK pada jenis kelamin tertentu, sehingga menyebabkan hasil yang bervariasi pada berbagai penelitian.

Pada penelitian ini sebagian besar didapatkan durasi otore selama 1-5 tahun, yaitu sejumlah 37 kasus $(33,33 \%)$ yang terbagi pada kelompok OMSK dengan kolesteatoma sejumlah 20 kasus $(35,09 \%)$, dan kelompok tanpa kolesteatoma sejumlah 17 kasus $(31,48 \%)$. Hasil ini sesuai dengan penelitian Winartoyo ${ }^{22}$ yang mendapatkan lama otore terbanyak adalah 1-5 tahun, yaitu sebanyak 37 kasus $(45,1 \%)$, meliputi kelompok kolesteatoma sebanyak 18 kasus (39\%), dan tanpa kolesteatoma sebanyak 19 kasus $(52,8 \%)$. Pada penelitian Kasliwal ${ }^{23}$ didapatkan lama otore terbanyak adalah 2-5 tahun yaitu 176 kasus $(34,5 \%)$, dan paling sedikit 11-15 tahun, yaitu 53 kasus (10,4\%). Secara deskriptif pada penelitian ini rata-rata durasi otore penderita OMSK yang menjalani mastoidektomi lebih lama didapat pada OMSK tanpa kolesteatoma yaitu 8,7 tahun. Pada OMSK dengan kolesteatoma didapat rerata 7,6 tahun. Hasil ini bertentangan dengan penelitian Winartoyo ${ }^{22}$ yang mendapatkan rerata durasi otore OMSK dengan kolesteatoma (7,5 tahun) lebih lama dibandingkan tanpa kolesteatoma (2,1 tahun). Hal ini dapat disebabkan karena sampel yang diambil pada penelitian ini adalah penderita OMSK yang sudah menjalani mastoidektomi.

Penderita OMSK dengan kolesteatoma lebih diprioritaskan untuk tindakan pembedahan mengingat risiko komplikasi, sehingga durasi otore penderita OMSK tanpa kolesteatoma terlihat lebih lama dibandingkan dengan kolesteatoma. Beberapa penelitian menyatakan adanya pengaruh durasi otore terhadap peningkatan ambang hantaran tulang. Untuk mengendalikan faktor tersebut maka durasi otore dijadikan sebagai faktor perancu dan dikontrol dengan uji statistik pada penelitian ini. Hasil uji statistik didapatkan tidak signifikan di semua frekuensi $(p=0,398)$.

Gangguan pendengaran pada OMSK paling banyak didapat jenis konduksi baik pada OMSK dengan kolesteatoma maupun tanpa kolesteatoma. Bentuk konduksi adalah bentuk yang paling sering dijumpai dengan perforasi membran timpani sebagai patogenesis dasar yang akan mengganggu proses konduksi gelombang suara. Bentuk gangguan pendengaran yang lain merupakan hasil interaksi dari berbagai hal, termasuk jenis OMSK, durasi otore, dan usia. Hal tersebut berujung pada keterlibatan telinga dalam.

Didapatkan satu penderita dengan pendengaran normal pada penderita OMSK dengan kolesteatoma, dan satu penderita SNHL dengan ambang dengar normal. Gangguan pendengaran mungkin ringan bahkan dapat normal sekalipun proses patologi yang terjdi sangat hebat. Hal ini terjadi kolesteatoma dapat menjadi penghantar suara yg baik atau dapat terjadi jika kolesteatoma berada di epitimpani. ${ }^{8}$ Secara deskriptif didapatkan derajat gangguan dengar OMSK dengan kolesteatoma lebih berat dibandingkan tanpa kolesteatoma. Penelitian ini sesuai dengan penelitian di Malang dan Medan yang juga mendapatkan ambang dengar penderita OMSK dengan kolesteatoma lebih tinggi dibanding tanpa kolesteatoma. ${ }^{18,22}$

Jenis OMSK tipe maligna cenderung menghasilkan derajat ketulian yang lebih parah. Hal ini disebabkan karena OMSK tipe maligna cenderung disertai dengan terbentuknya jaringan granulasi, edema, kolesteatoma, yang akan menyebabkan erosi tulang pendengaran. ${ }^{20}$ Prinsip pemeriksaan Air Conduction (AC) pada audiometri, memaparkan gelombang suara dari telinga luar hingga ke telinga dalam, dengan terbentuknya kondisi patologis yang menyertai OMSK tipe maligna, gelombang suara akan mengalami gangguan konduktivitas yang akan bermanifestasi sebagai peningkatan derajat ketulian.

Hasil audiometri yang tertera pada rekam medis penderita OMSK dengan kolesteatoma menunjukkan tendensi semakin tinggi frekuensi semakin besar nilai BC. Hasil yang sama juga didapat pada penelitian Sadasivan et al. ${ }^{4}$ dan Luntz et al. ${ }^{3}$ Hal ini menunjukkan bahwa kerusakan terjadi pada area frekuensi tinggi yang terletak di basal koklea. Dikatakan 
bahwa frekuensi yang sering terkena adalah 2000-4000 Hz. ${ }^{6}$ Pada penelitian ini ditemukan $4000 \mathrm{~Hz}$ adalah frekuensi dengan nilai BC tertinggi dibandingkan 500, 1000, dan 2000 Hz. Tuz et al. ${ }^{6}$ mengatakan beberapa peneliti berkonsensus bahwa frekuensi $4000 \mathrm{~Hz}$ adalah frekuensi yang paling berdampak pada OMSK.

Nilai BC pada frekuensi $2000 \mathrm{~Hz}$ didapat $31,23 \mathrm{~dB}$ dan pada frekuensi $4000 \mathrm{~Hz}$ didapat 31,84 dB. Dalam sebuah penelitian nilai BC $30 \mathrm{~dB}$ atau lebih diyakini sebagai adanya SNHL, cutting point ini digunakan untuk menyingkirkan kerusakan koklea yang tidak signifikan. ${ }^{11}$ Peningkatan ambang dengar BC $25 \mathrm{~dB}$ atau lebih, pada dua atau lebih frekuensi didefinisikan sebagai SNHL. ${ }^{4,24}$

Beberapa hipotesis menjelaskan mengapa nilai $\mathrm{BC}$ bisa meningkat pada OMSK. Diduga karena masuknya toksin melalui round window membrane (RWM) yang permeabilitasnya meningkat karena proses inflamasi kronik dari telinga tengah ke telinga dalam. Toksin ini akan merusak outer hair cells (OHC) dan inner hair cells (IHC) terutama pada bagian basal membran yang terdekat dengan RWM. Hal ini juga dibuktikan oleh beberapa penelitian post mortem yang menggunakan 15 tulang temporal OMSK dibandingkan dengan yang sehat, didapatkan perbedaan signifikan pada hilangnya sel rambut luar dan dalam yang ada pada bagian basal koklea. Putaran koklea lainnya tidak didapatkan perbedaan signifikan, dan tidak didapatkan adanya perbedaan pada fibrosit, luas area stria vascularis dan ligamen spiral pada basal koklea didapatkan menurun secara signifikan. ${ }^{25}$

Peningkatan $\mathrm{BC}$ dapat juga disebabkan oleh oklusi mekanik foramen ovale, sehingga menyebabkan over diagnosis SNHL. Jika demikian, maka peningkatan $\mathrm{BC}$ akan terlihat dominan pada frekuensi resonansi dari rantai osikel yaitu 1000-3000 Hz. Pada penelitian ini fiksasi stapes sudah dieksklusikan, sehingga peningkatan konduksi tulang pada penelitian ini menunjukkan murni karena gangguan fungsi koklea, dan terlihat nilai BC tertinggi adalah di frekuensi $4000 \mathrm{~Hz}$. Stenfelt dan Goode yang dikutip dari Luntz ${ }^{3}$ menyatakan tidak ada perubahan besar pada nilai BC pada frekuensi tinggi $\geq 4000 \mathrm{~Hz}$ atau frekuensi rendah $\leq 500 \mathrm{~Hz}$ jika penyebabnya adalah masalah telinga tengah, yang artinya pada kondisi ini sudah terjadi kerusakan telinga dalam.

Beberapa penelitian yang mendapatkan kolesteatoma merupakan faktor risiko terjadinya gangguan fungsi koklea pada OMSK berpendapat bahwa adanya kolesteatoma sering dihubungkan dengan inflamasi telinga tengah yang berkepanjangan. ${ }^{26}$ Kolesteatoma memproduksi toksin dan lytic enzyme dari epitel yang aktif, yang akan masuk ke telinga dalam, sehingga menyebabkan gangguan fungsi koklea.

Kolesteatoma dapat merupakan tanda agresivitas OMSK dan indikator munculnya SNHL. ${ }^{6}$ Berdasarkan beberapa teori, patofisiologi terjadinya kerusakan fungsi koklea pada OMSK yaitu masuknya toksin bakteri, dan mediator-mediator inflamasi dari telinga tengah ke dalam koklea melalui RWM. Kolesteatoma sendiri merupakan media yang sangat baik untuk pertumbuhan bakteri, sehingga infeksi menjadi persisten. ${ }^{13,27}$ Infeksi yang kronik dapat mengakibatkan menumpuknya mediator inflamasi tumor necrosis factor- $\alpha$ (TNF- $\alpha$ ), dan Interleukin$1 \beta$ yang menjadikan permeabilitas RWM semakin meningkat, sehingga bahanbahan tersebut akan lebih mudah masuk ke dalam koklea. Kolesteatoma juga dapat menyebabkan kerusakan tulang pada area kanalis semi sirkularis, sehingga mediator inflamasi juga dapat masuk ke dalam bagian yg terbuka tersebut.

Pada penelitian ini didapatkan hasil yang signifikan di seluruh frekuensi terutama frekuensi $1000 \mathrm{~Hz}$. Multiple regression menyatakan perbedaan yang signifikan $(\mathrm{p}=0,002)$ pada nilai rerata $\mathrm{BC}$ penderita kolesteatoma $(28,60 \mathrm{~dB} \mathrm{HL})$ dengan tanpa kolesteatoma (17,30 dB HL). Dengan demikian, hipotesis terdapat pengaruh kolesteatoma terhadap fungsi koklea pada penderita otitis media supuratif kronik terbukti. Rerata $\mathrm{BC}$ penderita OMSK dengan kolesteatoma sebesar 28,60 dB HL, menurut pembagian jenis gangguan dengar dan derajat 
gangguan dengar dikatakan tidak normal. Sementara itu, rerata BC pada OMSK tanpa kolesteatoma sebesar 17,30 dB HL, menurut pembagian jenis gangguan dengar dan derajat gangguan dengar dikatakan normal. Hal ini menunjukkan signifikansi yang didapat sesuai dengan gambaran klinis yang menggambarkan adanya gangguan fungsi koklea pada OMSK dengan kolesteatoma.

\section{DAFTAR PUSTAKA}

1. Lasisi AO, Olaniyan FA, Muibi SA, Azeez, Abdulwaisu KG, Imam ZO, et al. Clinical and demographic risk factors associated with chronic suppurative otitis media. International Journal of Pediatric Otorhinolaryngol.2007;71(10):1549-54.

2. Kolo ES, Salisu AD, Yaro AM, Nwaorgu OGB. Sensorineural hearing loss in patients with chronic suppurative otitis media. Indian Journal of Otolaryngol Head Neck Surg. 2012;64(1):59-62.

3. Luntz M, Yehudai N, Haifler M, Sigal G, Most T. Risk factors for sensorineural hearing loss in chronic otitis media. Acta Oto Laryngologica.2013;133(11):1173-80.

4. Sadasivan SS, Viswanatha B, Satish HS, Ravikumar R, Vijayashree MS, Datta RK, et al. A comparative study of sensorineural hearing loss in mucosal and squamous type of chronic otitis media. Research in Otolaryngology. 2015;4(1):13-7.

5. Sharma R, Sharma VK. Analysis of sensorineural hearing loss in chronic suppurative otitis media with and without cholesteatoma. Indian Journal of Otology.2012;18(2):65-8.

6. Tuz M, Dogru H, Doner F, Yasan H, Aynali G. Sensorineural hearing loss associated with chronic otitis media. SDU Tip Fak Der. 2006;13(1):1-4.

7. Telian SA, Schmalbach SE. Chronic otitis media. In: Snow JB, Ballenger JJ, editors. Ballenger's Otorhinolaryngology Head and Neck Surgery $16^{\text {th }}$ ed. Ontario: BC Decker Inc; 2003.p.261-5.

8. Helmi. Otitis media supuratif kronik edisi 1. Jakarta: Fakultas Kedokteran Universitas Indonesia;2005.p.55-72.
9. Meyer TE, Strunk CL, Lambert PR. Choleasteatoma. In: Bailey BJ, Jonhson JT, Newlands SD, editors. head and neck surgery otolaryngology $4^{\text {th }}$ ed. Philadelphia: Lippncot William \& Wilkins;2006. p.208291.

10. Wisnubroto. Dampak akibat otitis media kronik. Kumpulan Naskah Ilmiah Kongres Nasional PERHATI-KL XIII, Bali, 2003.

11. Azevedo AF, Pinto DC, Souza NJ, Greco D, Goncalves DU. Sensorineural hearing loss in chronic suppurative otitis media with and without cholesteatoma. Rev Bras Otorrinolaringol. 2007;73(5):671-4

12. Hall JW, Bantwal AR. Phsyiology of hearing. In: Kirtane, MV, Souza CE. Otology and neurotology. 2013. India: Thieme. p.47.

13. Wahyudiono $\mathrm{AD}$, Winartoyo $\mathrm{S}$, Wardhani V, Handoko E. The role of cholesteatoma on the bone conduction threshold in chronic suppurative otitis media. In: Cholesteatoma and Ear Surgery. Amsterdam: Kugler Publication; 2013.p.321-3.

14. Yehudai N, Most T, Luntz M. Risk factors for sensorineural hearing loss in pediatric chronic otitis media. International Journal of Pediatric Otorhinolaryngol. 2015;79(1):2630.

15. Nursiah S. Pola kuman aerob penyebab omsk dan kepekaan terhadap beberapa antibiotika di Bagian THT FK USU/ RSUP H. Adam Malik Medan. 2016. Available from:http://repository.usu.ac.id/ bitstream/123456789/6436/1/tht-siti\%20 nursiah.pdf.

16. Acuin J. Chronic suppurative otitis media: burden of illness and management option. Child and adolescent health and development prevention of blindness and deafness. Switzerland: WHO, 2004.

17. Dewi NP \& Zahara D. Gambaran pasien otitis media supuratif kronik (OMSK) di RSUP H. Adam Malik Medan. E-Journal FK USU. 2013;1(1):1-6.

18. Suwanto D. Hubungan jenis otitis media supuratif kronik dengan gangguan pendengaran di rumah sakit umum pusat haji adam malik medan. Tesis. Medan: Pascasarjana Fakultas Kedokteran Universitas Sumatera Utara; 2012. 
19. Kaur K, Sonkhya N, Bapna S. Chronic suppurative otitis media and sensorineural hearing loss: is there a correlation? Indian Journal of Otolaryngology and Head and Neck Surgery. 2003;55:21-4.

20. Islam MS, IslamMR, Bhuiyan MAR, Rashid MS, Datta PG. Pattern and degree of hearing loss in chronic otitis media. Bangladesh J Otorhinolaryngol. 2011;16(2):6844.

21. Faridah M, Rahardjo SP, Pieter NAL. Otitis media prevalence in primary school children in Makassar. The Indonesian Journal of Medical Science. 2010;1(7):385-91.

22. Winartoyo S. Perbedaan risiko tuli sensorineural antara otitis media supuratif kronis dengan kolesteatoma dan tanpa kolesteatoma. Tesis. Malang: Pascasarjaran Fakultas Kedokteran Universitas Brawijaya; 2010.

23. Kaliswal N, Joshi S, Pareek SM, Determinants of sensorineural hearing loss in chronic middle-ear disease. Indian Journal of Otolaryngology and Head and Neck Surgery. 2004;56(4):269-73.
24. Mohsin MA, Kumar M, Reddy B, Ravikumar D, Pradesh A. Sensorineural hearing loss in chronic suppurative otitis media of tubotympanic variety. National Journal of Otorhinolaryngol Head and Neck Surgery. 2013;1(10):41-5.

25. Cureoglu S, Schachern PA, Paparella MM, Lindgren BR. Cochlear changes in chronic otitis media. Laryngoscope. 2009;114(4):622-6.

26. Zinis LO, Campovecchi C, Parrinello G, Antonelli AR. Predisposing factors for inner ear hearing loss association with chronic otitis media. Internationa Journal of Audiology. 2005;44(10):593-8.

27. Netto LF, Costa SS, Sleifer P, Braga ME. The impact of chronic suppurative otitis media on children's and teenager's hearing. International Journal of Pediatric Otorhinolaryngology.2009;73(12):1751-6. 